\title{
Industry 4.0 Implementation and Corporate Strategies under the Conditions of Slovak Republic
}

\author{
Marian Halaj ${ }^{1}$ \\ ${ }^{1}$ Comenius University, Odbojarov 10, 82005 Bratislava, Slovakia \\ marian.halajefm.uniba.sk
}

\begin{abstract}
This paper deals with the strategies for successful implementation of Industry 4.0 under the local conditions. The study is based on the analyze of the companies operated in Slovak republic and respects the country specific phenomena like export orientation, high percentage of international and foreign owned manufacturing companies, existing IT infrastructure, analytical maturity and labor market. As a framework for holistic analyze the McKinsey 7S model is used that takes into consideration corporate strategy, organization structure, systems, skills, staff, corporate shared values and management style. The weights of its elements for the purpose of multi-criteria decision-making are calculated using analytical hierarchy process (AHP).
\end{abstract}

Keywords: Industry 4.0, Strategy, Innovation, Business Intelligence

\section{Industry 4.0 and a Smart Revolution}

Within the last five perhaps ten years there have been exhaustive discussions on how the technology disrupt the world economics and the phenomena called the Fourth Industrial Revolution, also called Industry 4.0 (see Fig. 1). This revolution is characterized by a range of new technologies that are fusing physical and digital world, impacting all disciplines and industries

The Industry 4.0 is often associated with the Internet of Things that is a huge set of intelligent sensors interconnected using high speed internet. Even more often the Industry 4.0 is referred to Cyber-Physical Systems (CPS). The CPS are systems of collaborating computational entities which are in intensive connection with the surrounding physical world and its on-going processes, providing and using, at the same time, data-accessing and data-processing services available on the internet [1]. The typical example of CPS is a modern manufacturing plant where the robots interact with another production and control systems. 


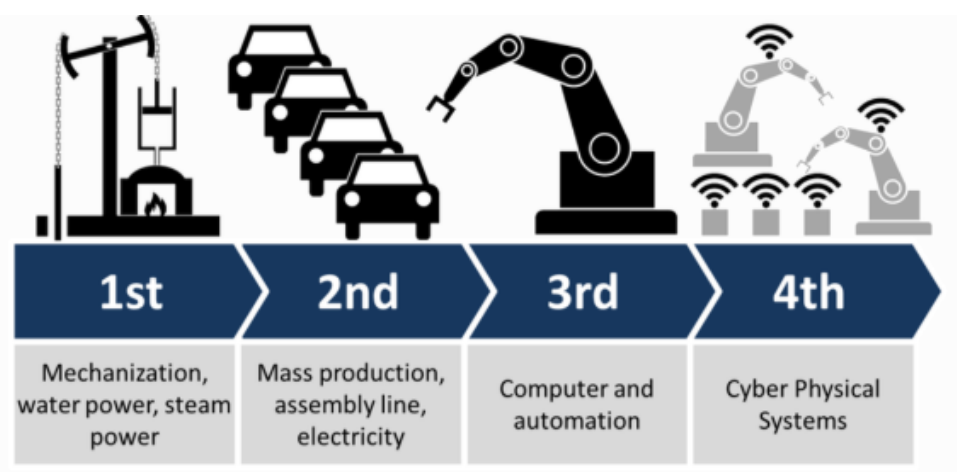

Fig. 1. The 4 Industrial Revolutions [2].

\subsection{Investments in Industry 4.0}

The Industry 4.0 brings a value to the business by effective and reliable production control, high level of outputs and very fast translation of corporate strategies into a production, but there are some drawbacks as well. For example, as automation increases, computers and machines will replace workers, especially the low skilled ones. The investments in Industry 4.0 are also a significant factor, therefore the rich countries will benefit over the poor ones.

As per PWC industrial sectors are planning to commit US\$907 bn p.a. to Industry 4.0 (around $5 \%$ of revenue p.a). A major focus of these investments will be on digital technologies like sensors or connectivity devices, and on software and applications like manufacturing execution systems [3].

Maar claims any factory or system considered Industry 4.0, it must include interoperability of technologies, information transparency, technical assistance of systems and humans in making decisions and decentralized decision-making. To address these queries, he suggests five major challenges for Industry 4.0 [4]:

- Data security issues are greatly increased by integrating new systems and more access to those systems.

- A high degree of reliability and stability are needed for successful cyberphysical communication that can be difficult to achieve and maintain.

- Maintaining the integrity of the production process with less human oversight could become a barrier.

- Loss of high-paying human jobs is always a concern when new automations are introduced.

- And avoiding technical problems that could cause expensive production outages is always a concern. 


\subsection{Business Intelligence as a mean to reach the corporate Objectives}

The Business intelligence (BI) represents a powerfull tool for business process optimization. Generally we can describe BI as an integrated and (in some extent) automated set of systems or processes consisting of technology, hardware, operation systems, applications and techniques with the interface to people operating these systems and based on that operations allowing them to make the qualified and actionable decisions towards business needs. The BI is normally equipped with the automation of the data collection, sourcing and extracting from another systems and databases, like. In addition to usual type of data (e.g. accounting, HR databases, quality measurements, etc.) specially in the Industry 4.0 manufacturing firms these data data includes also those comming from intelligent sensors, field instrumenantion and SCADA.

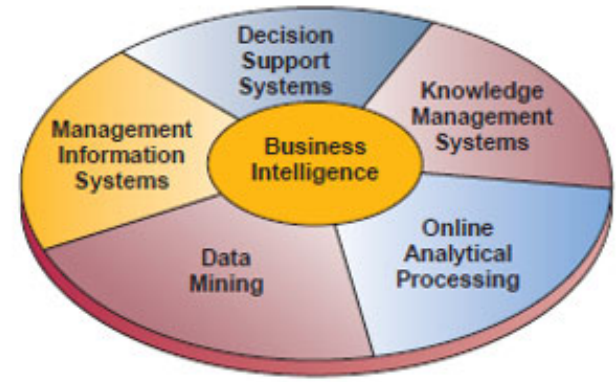

Fig. 2. BI applications [5].

As shown on Fig. 2 BI applications are based on personalized and Web enabled information analysis, knowledge management, and decision support technologies. The core of the BI system is the data loading from various data sources, data treatment, analyze using statistical tools and heuristic rules as well as advanced reporting and decision support.

\section{Corporate Performance and Strategies}

The concept of 7S (Fig. 3) was developed within a task force of McKinsey \& Company in a response to general problem of organization effectiveness. This proposed framework represents the relationship between seven elements (variables) of the organization. The model is based on the theory that, for an organization to perform well, these seven elements need to be aligned and mutually reinforcing. So, the model can be used to help identify what needs to be realigned to improve performance, or to maintain alignment (and performance) in case of any change. The model structure does not have a start, neither an end point, therefore the system alignment can start by any element. The seven elements of the framework mean:

Strategy - purpose of the business and the way the organization seeks to enhance its competitive advantage. Most of the corporate strategies within the surveyed companies 
come out of the product, process and organization innovations in order to improve their positions on the markets abroad. Another important aspect of corporate strategy is the time. As per [7] the life cycle of new technologies falls down to 3 years.

Structure takes into a consideration the existing corporate organization structures and an expected shift from traditional organizations toward projects and flexible team structures to cope with a complex task under higher level of time stress.

- Systems include formal procedures for measurement, reward and resource allocation, however the technologies and information systems as well. As per McKinsey survey [8] the companies will benefit by Industry 4.0 implementation as follows: $30-50 \%$ reduction in machine downtime, $15-30 \%$ improvements in productivity, $10-30 \%$ increase in throughput, $10-20 \%$ decrease in quality cost.

- Superordinate goals is the most intuitive and hardly measurable element of the model and needs more research on its definition. This perspective takes into consideration mainly the business case for companies and the organization cultures. The major contributor to the Slovak export is the automotive industry and electronics that is almost exclusively made of international companies. Their business justifications and intercultural issues are always different to the "standard businesses".

- Skills are organization's core competencies and distinctive capabilities. Here we need to distinguish between organizational competences represented by references, lessons learned, etc., and individual's ones.

- Staff - organization's human resources that are further specified by competencies, education, etc.

- Style represents the management style within organizations. It is affected by management individualities, labor code and structure of ownership.

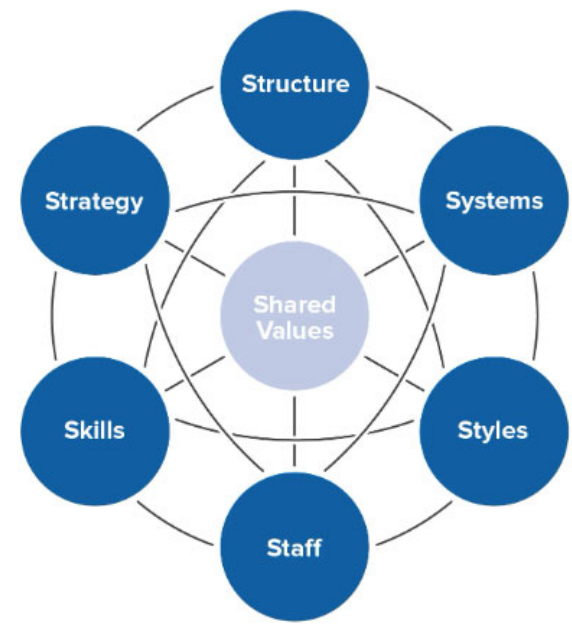

Fig. 3. The McKinsey 7S [6]. 


\section{The case for Slovak republic}

The source data to perform the study have been retrieved from the questionnaires of over 300 companies operating in Slovak republic [9], [10], [11] and for consistency empirically validated by questioning the line and senior management from three different businesses, where Schneider Electric represents the electrical engineering, Jaguar Land Rover is considered as a typical Industry 4.0 manufacturing facility and Slovenske Elektrarne MO34 represents a large construction project, that is not an export oriented company but fills a gap in Industry 4.0 purpose definition.

As per Industry4um survey $40 \%$ of Slovak companies has already launched the implementation phase of their Industry 4.0 strategy in 2019 [9]. The same study also investigated the corporate's expectations of these strategies.

- $21 \%$ of respondents stated they expect the development of new business model

- $54 \%$ of respondents expects the improvement in supply chain efficiency

- $\quad 98 \%$ - an overwhelming majority of respondents - expects this strategy to improve the performance and efficency of their internal processes.

Taking into consideration these statistics and growing trend we can assume of Industry 4.0 investments and expectations will lead to the pressure on the production market. That will shortly turn the competitive advantage into a competitive necessity when the successful innovation will be followed by competitors and the previous advantage will turn into a need to survive.

We can broadly consider the Industry 4.0 as a part of innovations field. As Slovakia is export oriented country we will use the innovation impact on the demand for Slovak products abroad as an indicator of Industry 4.0 implementation effectivity. As per Fig. 5 the demand for Slovak products abroad has a growing trend within the last years (from $43,4 \%$ in 2015 to $73,58 \%$ in 2018 ) that is mainly caused by process and organizational innovations.

Impact of product innovation on the abroad demand

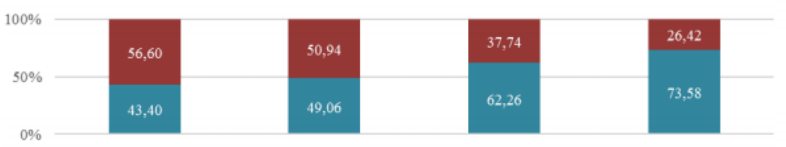

Impact of process innovation on the abroad demand

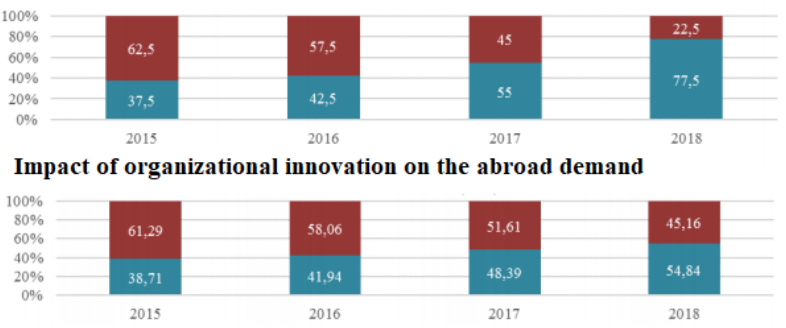


Fig. 4. Impact of innovations on the abroad demand [10].

The study published by RUZ [11] suggests focus on four areas of Industry $4.0 \mathrm{im}$ plementation: education policy, physical and IT infrastructure, intellectual property and labor code.

Our empirical survey on coprorate managers confirm the need for focus in infrastructure investments, process and systems innovation, but in general they neglect the need for public education as they claim these systems are corporate specific. Rather, they prefere an extensive trainings within the particular organization.

\section{Analytical Application}

The application part searches for the most significant Industry 4.0 implementation drivers by analyzing the 7S model under the conditions of Slovak republic. These is realized by numerical calculation of suggested 21 alternatives developed from $7 \mathrm{~S}$ elements.

The major concern in identification of the most promising alternatives in multi-criterial decision-making is always the choice of criteria weight. In this case the Analytical Hierarchy Process (AHP) has been used to define these weighs by a pairwise comparison of all alternatives using an expert knowledge. Calculation has been performed using bpmsg tool [12].

The expert knowledge has been extracted from [9], [10], [11], empirical survey and prioritized to develop the heuristic rules "which priorities" and "how much more" that is on scale 1-9 where 1 is equal and 9 is extreme importance. The AHP process is presented in Fig. 5 and results in Fig. 6. The criteria for accepting AHP as a consistent in rules application is the contingency ration $\mathrm{CR}<10 \%$ that. In our case the $\mathrm{CR}=8,8 \%$ which is within the limits of consistency.

The 7S model does not have a start or end point so we have decided to start from strategy as this is the most frequently discussed topic within reviewed Industry 4.0 studies. Therefore, the strategy is also considered as more important comparing to any other $7 \mathrm{~S}$ elements, except systems as these include the technologies and cyber-physical systems. Strategy and systems are considered as of equal importance. With respect to the trend of transition from existing organization structures towards organic project and team ones the structure is considered as a least important of all other aspects in relation to strategy. The strategy itself is represented in $7 \mathrm{~S}$ model by four most significant ones that are product, process and organizational innovation [10], as well as by a new business model [3], [13], [14].

The weakest elements of the model are shared values and management style that are hard to define as there are no commonly accepted performance indicators on those. The further research on this topic could affect the results of this study substantially in some particular businesses. 
The study has identified four critical drivers of the Industry 4.0 implementation drivers that are Process innovation (18,2\%), Advanced and analytical skills (17,19\%), Product innovation $(8,89 \%)$ and IT Infrastructure $(7,2 \%)$.

\begin{tabular}{|c|c|c|c|c|}
\hline \multicolumn{3}{|c|}{ A - wrt AHP priorities - or B? } & \multirow{2}{*}{$\begin{array}{l}\text { Equal } \\
\mathrm{O}_{1}\end{array}$} & \multirow{2}{*}{$\begin{array}{c}\text { How much more? } \\
\mathrm{O}_{2} \mathrm{O}_{3} \mathrm{O}_{4} \mathrm{O}_{5} \mathrm{O}_{6} \mathrm{O}_{7} \mathrm{O}_{8} \mathrm{O}_{9}\end{array}$} \\
\hline 1 & (O) Strategy & Structure & & \\
\hline 2 & () Strategy & OSystems & $0_{1}$ & $\mathrm{O}_{2} \mathrm{O}_{3} \mathrm{O}_{4} \mathrm{O}_{5} \mathrm{O}_{6} \mathrm{O}_{7} \mathrm{O}_{8} \mathrm{O}_{9}$ \\
\hline 3 & O Strategy & Oskills & $\mathrm{O}_{1}$ & $\mathrm{O}_{2} \mathrm{O}_{3} \mathrm{O}_{4} \mathrm{O}_{5} \mathrm{O}_{6} \mathrm{O}_{7} \mathrm{O}_{8} \mathrm{O}_{9}$ \\
\hline 4 & O Strategy & OStaff & $\mathrm{O}_{1}$ & $\mathrm{O}_{2} \mathrm{O}_{3} \mathrm{O}_{4} \mathrm{O}_{5} \mathrm{O}_{6} \mathrm{O}_{7} \mathrm{O}_{8} \mathrm{O}_{9}$ \\
\hline 5 & () Strategy & OShared values & $\mathrm{O}_{1}$ & $\mathrm{O}_{2} \mathrm{O}_{3} \mathrm{O}_{4} \mathrm{O}_{5} \mathrm{O}_{6} \mathrm{O}_{7} \mathrm{O}_{8} \mathrm{O}_{9}$ \\
\hline 6 & ( ) Strategy & Style & $\mathrm{O}_{1}$ & $\mathrm{O}_{2} \mathrm{O}_{3} \mathrm{O}_{4} \mathrm{O}_{5} \mathrm{O}_{6} \mathrm{O}_{7} \mathrm{O}_{8} \mathrm{O}_{9}$ \\
\hline 7 & O Structure & OSystems & $0_{1}$ & $\mathrm{O}_{2} \mathrm{O}_{3} \mathrm{O}_{4} \mathrm{O}_{5} \mathrm{O}_{6} \mathrm{O}_{7} \mathrm{O}_{8} \mathrm{O}_{9}$ \\
\hline 8 & (C) Structure & Oskills & $0_{1}$ & $\mathrm{O}_{2} \mathrm{O}_{3} \mathrm{O}_{4} \mathrm{O}_{5} \mathrm{O}_{6} \mathrm{O}_{7} \mathrm{O}_{8} \mathrm{O}_{9}$ \\
\hline 9 & O Structure & Ostaff & $\mathbf{O}_{1}$ & $\mathrm{O}_{2} \mathrm{O}_{3} \mathrm{O}_{4} \mathrm{O}_{5} \mathrm{O}_{6} \mathrm{O}_{7} \mathrm{O}_{8} \mathrm{O}_{9}$ \\
\hline 10 & O Structure & OShared values & O 1 & $\mathrm{O}_{2} \mathrm{O}_{3} \mathrm{O}_{4} \mathrm{O}_{5} \mathrm{O}_{6} \mathrm{O}_{7} \mathrm{O}_{8} \mathrm{O}_{9}$ \\
\hline 11 & O Structure & OStyle & $\mathrm{O}_{1}$ & $\mathrm{O}_{2} \mathrm{O}_{3} \mathrm{O}_{4} \mathrm{O}_{5} \mathrm{O}_{6} \mathrm{O}_{7} \mathrm{O}_{8} \mathrm{O}_{9}$ \\
\hline 12 & (C) Systems & Oskills & $\mathrm{O}_{1}$ & $\mathrm{O}_{2} \mathrm{O}_{3} \mathrm{O}_{4} \mathrm{O}_{5} \mathrm{O}_{6} \mathrm{O}_{7} \mathrm{O}_{8} \mathrm{O}_{9}$ \\
\hline 13 & (1) Systems & OStaff & $\mathrm{O}_{1}$ & $\mathrm{O}_{2} \mathrm{O}_{3} \mathrm{O}_{4} \mathrm{O}_{5} \mathrm{O}_{6} \mathrm{O}_{7} \mathrm{O}_{8} \mathrm{O}_{9}$ \\
\hline 14 & () Systems & OShared values & $\mathrm{O}_{1}$ & $\mathrm{O}_{2} \mathrm{O}_{3} \mathrm{O}_{4} \mathrm{O}_{5} \mathrm{O}_{6} \mathrm{O}_{7} \mathrm{O}_{8} \mathrm{O}_{9}$ \\
\hline 15 & (C) Systems & OStyle & $\mathrm{O}_{1}$ & $\mathrm{O}_{2} \mathrm{O}_{3} \mathrm{O}_{4} \mathrm{O}_{5} \mathrm{O}_{6} \mathrm{O}_{7} \mathrm{O}_{8} \mathrm{O}_{9}$ \\
\hline 16 & (O) Skills & Staff & $\mathrm{O}_{1}$ & $\mathrm{O}_{2} \mathrm{O}_{3} \mathrm{O}_{4} \mathrm{O}_{5} \mathrm{O}_{6} \mathrm{O}_{7} \mathrm{O}_{8} \mathrm{O}_{9}$ \\
\hline 17 & (O) Skills & OShared values & $\mathrm{O}_{1}$ & $\mathrm{O}_{2} \mathrm{O}_{3} \mathrm{O}_{4} \mathrm{O}_{5} \mathrm{O}_{6} \mathrm{O}_{7} \mathrm{O}_{8} \mathrm{O}_{9}$ \\
\hline 18 & () Skills & OStyle & $\mathrm{O}_{1}$ & $\mathrm{O}_{2} \mathrm{O}_{3} \mathrm{O}_{4} \mathrm{O}_{5} \mathrm{O}_{6} \mathrm{O}_{7} \mathrm{O}_{8} \mathrm{O}_{9}$ \\
\hline 19 & (1) Staff & OShared values & $0_{1}$ & $\mathrm{O}_{2} \mathrm{O}_{3} \mathrm{O}_{4} \mathrm{O}_{5} \mathrm{O}_{6} \mathrm{O}_{7} \mathrm{O}_{8} \mathrm{O}_{9}$ \\
\hline 20 & O Staff & OStyle & $\mathrm{O}_{1}$ & $\mathrm{O}_{2} \mathrm{O}_{3} \mathrm{O}_{4} \mathrm{O}_{5} \mathrm{O}_{6} \mathrm{O}_{7} \mathrm{O}_{8} \mathrm{O}_{9}$ \\
\hline 21 & (O) Shared values & OStyle & $\mathrm{O}_{1}$ & $\mathrm{O}_{2} \mathrm{O}_{3} \mathrm{O}_{4} \mathrm{O}_{5} \mathrm{O}_{6} \mathrm{O}_{7} \mathrm{O}_{8} \mathrm{O}_{9}$ \\
\hline \multicolumn{5}{|c|}{$C R=0 \%$ Please start pairwise comparison } \\
\hline \begin{tabular}{|c|}
$\mathrm{Ca}$ \\
\end{tabular} & culate & & & \\
\hline
\end{tabular}


Fig. 5. AHP Process [10]

\begin{tabular}{|c|c|c|c|c|c|}
\hline \multicolumn{6}{|c|}{ Priorities } \\
\hline \multicolumn{6}{|c|}{$\begin{array}{l}\text { These are the resulting weights for the criteria } \\
\text { based on your pairwise comparisons: }\end{array}$} \\
\hline $\mathrm{Ca}$ & & Priority & Rank & $(+)$ & $(-)$ \\
\hline 1 & Strategy & $34.6 \%$ & 1 & $20.8 \%$ & $20.8 \%$ \\
\hline 2 & Structure & $10.4 \%$ & 4 & $5.2 \%$ & $5.2 \%$ \\
\hline 3 & Skills & $22.1 \%$ & 2 & $13.1 \%$ & $13.1 \%$ \\
\hline 4 & Staff & $9.0 \%$ & 5 & $3.1 \%$ & $3.1 \%$ \\
\hline 5 & Systems & $14.7 \%$ & 3 & $8.5 \%$ & $8.5 \%$ \\
\hline 6 & Shared values & $6.8 \%$ & 6 & $1.6 \%$ & $1.6 \%$ \\
\hline 7 & Style & $2.4 \%$ & 7 & $1.0 \%$ & $1.0 \%$ \\
\hline
\end{tabular}

Number of comparisons $=21$ Consistency Ratio CR $=8.8 \%$

\section{Decision Matrix}

The resulting weights are based on the principal eigenvector of the decision matrix:

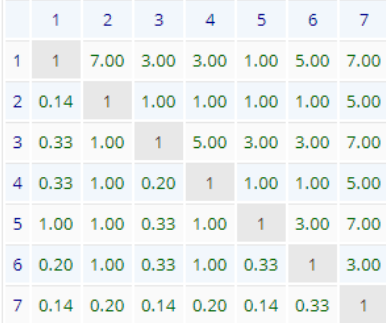

Principal eigen value $=7.710$

Eigenvector solution: 6 iterations, delta $=1.9 \mathrm{E}-8$

Fig. 6. Results of AHP for 7S elements

If we look scroll back to 1.2 we can see the BI model addresses very similar issue, i.e. the process and product innovation corresponds to the management information system and online analytical processing, while the strategy implementation is driven by decision support systems. As the strategy contributes to Industry 4.0 by one third we suggest companies to give the automated decision-support system high level of their attention.

Advanced and analytical skills as a second largest contributor to Industry 4.0 efficient implementation is involved into all segments of BI model, therefore we can say there is a direct proportion between employes analytical qualification / skills and a business success in the era of Fourth Industrial Revolution. 
Table 1. Industry 4.0 major contributors.

\begin{tabular}{|c|c|c|c|c|}
\hline Category & Priority & Sub-category & Priority & Total Contribution \\
\hline Strategy & $34,60 \%$ & $\begin{array}{l}\text { Product innovation } \\
\text { Process innovation } \\
\text { Organizational innovation } \\
\text { New business models } \\
\end{array}$ & $\begin{array}{l}25,70 \% \\
52,60 \% \\
15,40 \% \\
6,30 \% \\
\end{array}$ & $\begin{array}{l}8,89 \% \\
18,20 \% \\
5,33 \% \\
2,18 \% \\
\end{array}$ \\
\hline Structure & $10,40 \%$ & $\begin{array}{l}\text { Team org structures } \\
\text { Project environment }\end{array}$ & $\begin{array}{l}50,00 \% \\
50,00 \% \\
\end{array}$ & $\begin{array}{l}5,20 \% \\
5,20 \% \\
\end{array}$ \\
\hline Systems & $14,70 \%$ & $\begin{array}{l}\text { Availability of info on Industry } 4.0 \\
\text { IT Infrastructure } \\
\text { Digital maturity } \\
\text { Technology Investments } \\
\text { M2M communication } \\
\text { Data security issues }\end{array}$ & \begin{tabular}{|l|}
$2,50 \%$ \\
$49,00 \%$ \\
$12,20 \%$ \\
$20,20 \%$ \\
$13,10 \%$ \\
$3,00 \%$ \\
\end{tabular} & \begin{tabular}{l|}
$0,37 \%$ \\
$7,20 \%$ \\
$1,79 \%$ \\
$2,97 \%$ \\
$1,93 \%$ \\
$0,44 \%$ \\
\end{tabular} \\
\hline Skills & $22,10 \%$ & $\begin{array}{l}\text { Advanced and analytical skills } \\
\text { Labor } \\
\text { Technical skills } \\
\end{array}$ & $\begin{array}{l}77,80 \% \\
11,10 \% \\
11,10 \% \\
\end{array}$ & $\begin{array}{l}17,19 \% \\
2,45 \% \\
2,45 \% \\
\end{array}$ \\
\hline Staff & $9,00 \%$ & $\begin{array}{l}\text { Senior management comittment } \\
\text { Corporate learning initiatives } \\
\text { Support of public eduction } \\
\text { Corporate learning attitude }\end{array}$ & $\begin{array}{l}58,80 \% \\
11,80 \% \\
21,90 \% \\
7,60 \% \\
\end{array}$ & $\begin{array}{l}5,29 \% \\
1,06 \% \\
1,97 \% \\
0,68 \% \\
\end{array}$ \\
\hline Shared values & $6,80 \%$ & Shared values & $100,00 \%$ & $6,80 \%$ \\
\hline Style & $2,40 \%$ & $\begin{array}{l}\text { Labor code } \\
\text { Local ownership }\end{array}$ & $\begin{array}{l}70,00 \% \\
30,00 \% \\
\end{array}$ & $\begin{array}{l}1,68 \% \\
0,72 \% \\
\end{array}$ \\
\hline
\end{tabular}

\section{Conclusion}

The study has identified four critical Industry 4.0 implementation drivers under the conditions of Slovak republic and the business located here: process innovation, advanced and analytical skills, product innovation and IT Infrastructure. Except the last one the major drivers are not directly linked with high investment expenditures of private sector that might be found important discovery for the small and medium-size businesses planning to operate in Industry 4.0 environment.

The main emphasis is put on the strategy definition and implementation systems like management information system and online analytical processing of production data that are identified as key components of a corporate success.

Advanced and analytical skills are found as a second largest contributor to Industry 4.0 efficient implementation is involved into all segments of BI model, therefore we can say there is a direct proportion between employee analytical qualification / skills and a business success in the era of Fourth Industrial Revolution.

The study has also suggested companies to give the automated decision-support system high level of their attention as they may contribute to the overall business success by one third. 
The weakest elements of the study are found the shared values and management style that are hard to define as there are no commonly accepted performance indicators on those. The further research on this topic is suggested to strengthen the model validity.

\section{References}

1. www.springer.com/CIRP Encyclopedia of Production Engineering

2. https://www.weforum.org/pages/the-fourth-industrial-revolution-by-klaus-schwab

3. Industry 4.0: Building the digital enterprise. 2016. PWC: Global Industry 4.0 Survey. 36p.

4. Marr, B. 2016. What Everyone Must Know About Industry 4.0. In: Forbes. Available at: $<$ https://www.forbes.com/sites/bernardmarr/2016/04/05/why-everyone-must-get-readyfor-4th-industrial-revolution/\#12fa6243f90b>

5. O'Brien, J. A. - Marakas, G. M. 2011, Management Information Systems, 10th Edition, McGrawHill, New York, USA.

6. www.mindtools.com

7. Okruhlica, F. - Marsina, S. 2012. Actual Comprehension of the Project as a Tool of Innovation Strategy Implementation. In. Ekonomicky casopis, 60, 2012, pp. 495-508.

8. https://www.manufacturingglobal.com/technology/mckinsey-five-principles-scaling-digital-manufacturing

9. Ako sa meni pristup firiem v SR k aplikacii Industry 4.0. 2019. In: Industry4um. www.industry4um.sk. 2019. 23p.

10. Ziga, P. 2020. Správa o výsledkoch a záveroch prieskumu o vplyve inovácií a podporných nástrojov na exportnú výkonnost' spoločností v Slovenskej republike. Bratislava: Ministry of Economy of the Slovak Republic. 36p.

11. Composite Authors. 2017. Analýza dopadov digitálnej transformácie na podnikatel’ov, v súkromnom a verejnom sektore. In: RUZ. 2017. 149p.

12. https://bpmsg.com/ahp/

13. Industry 4.0 at McKinsey's model factories. 2016. McKinsey \& Company. 12p.

14. Industry 4.0 How to navigate digitization of the manufacturing sector. 2015. McKinsey \& Company. 62p. 